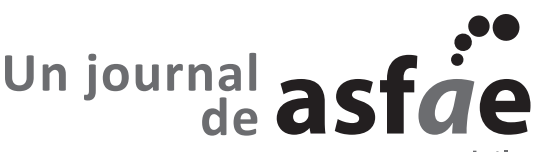 \\ chile
}

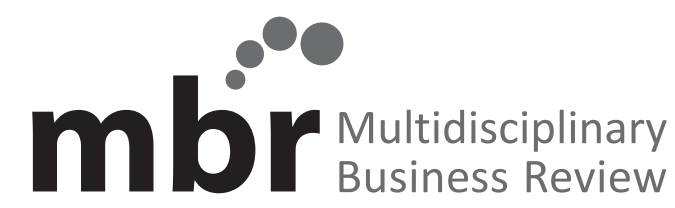

\section{HOW CAN ACCELERATORS IN SOUTH AMERICA EVOLVE TO SUPPORT START-UPS IN A POST-COVID-19 WORLD?}

\author{
¿CÓMO PUEDEN EVOLUCIONAR LOS ACELERADORES EN SUDAMÉRICA \\ PARA APOYAR LAS INICIACIONES EN UN MUNDO POST-COVID-19?
}

\author{
Diane A. Isabelle ${ }^{a *} \cdot$ Nicola Del Sarto ${ }^{b}$ \\ Classification: Conceptual Paper \\ Received: May 16, 2020 / Revised: July 24, 2020 / Accepted: September 11, 2020
}

\begin{abstract}
The COVID-19 pandemic has affected the world in drastic ways, disrupting the normal operation of the world's economic activity. Every aspect of life as we know it has changed. The business and entrepreneurship landscapes have been deeply altered. As innovation intermediaries support entrepreneurship, accelerators have become progressively prominent in the entrepreneurial ecosystem of several countries. Their development is on an upward trajectory. However, literature is scant on this newer acceleration phenomenon, particularly in some regions. Furthermore, literature on the effects of the pandemic on accelerators is non-existent. In recent years, the acceleration model has grown rapidly in South America. In this rapid response paper, we build from current literature, trends and expected post-COVID-19 scenarios to investigate how accelerators in South America will need to evolve to support start-ups in a post-COVID-19 world. We developed a conceptual model, the Post-COVID-19 World Accelerator Model, to guide business accelerator managers, researchers, policymakers and entrepreneurs. We conclude by offering future research areas urgently needed to further our understanding of emerging trends affecting accelerators and start-ups in what will be a very different business landscape post-COVID-19.
\end{abstract}

Keywords: accelerators, post-COVID-19 world, start-ups, entrepreneurship, accelerator model, South America.

\section{Resumen}

La pandemia de COVID-19 ha afectado al mundo de manera drástica, interrumpiendo el funcionamiento normal de la actividad económica mundial. Cada aspecto de la vida tal como la conocemos ha cambiado. El panorama empresarial y de emprendimiento se ha modificado profundamente. Como intermediarios de la innovación que apoyan el espíritu empresarial, los aceleradores se han vuelto progresivamente importantes en el ecosistema empresarial de varios países. Su desarrollo sigue una trayectoria ascendente. Sin embargo, la literatura es escasa sobre este nuevo fenómeno de aceleración, particularmente en algunas regiones. Además, no existe literatura sobre los efectos de la pandemia en los aceleradores. En los últimos años, el modelo de aceleración ha crecido rápidamente en América del Sur. En este artículo de respuesta rápida, nos basamos en la literatura actual, las tendencias y los escenarios esperados posteriores al COVID-19 para investigar cómo los aceleradores en América del Sur deberán evolucionar para apoyar a las empresas emergentes en un mundo posterior al COVID-19. Desarrollamos un modelo conceptual, el modelo acelerador mundial postCOVID-19, para guiar a los gerentes, investigadores, legisladores y emprendedores de aceleradores de negocios. Concluimos ofreciendo áreas de investigación futuras que se necesitan con urgencia para

Sprott School of Business. Carleton University. Ottawa, Canada. Email: diane.isabelle@carleton.ca

Istituto di Management, Scuola Superiore Sant'Anna, Pisa, Italy. Email: nicola.delsarto@sssup.it 
comprender mejor las tendencias emergentes que afectan a las aceleradoras y las empresas emergentes en lo que será un panorama empresarial muy diferente después de COVID-19.

Palabras clave: aceleradores, mundo postCOVID-19, start-ups, emprendimiento, modelo acelerador, Sudamérica.

\section{Introduction}

The COVID-19 pandemic has created an unprecedented exogenous shock to individuals and businesses, creating severe economic concerns with expected long-lasting negative impacts (Fernandes, 2020; Kuckertz et al., 2020). The uncertainties surrounding health and operational solutions to deal with the current and potential subsequent epidemic waves are creating a very uncertain new world. In a post-COVID-19 world, every facet of business activity will be affected, some quite profoundly. Conversely, the post-COVID-19 future will also bring exceptional opportunities for novel products, services and business models.

Innovation and entrepreneurship will be essential to move economies on a path of recovery and resiliency. Accelerators, a new institutional form to support early stage start-ups, a term which refers to a company in its first stage of operations, are an important innovation actor of entrepreneurial ecosystems (Bliemel, Flores, De Klerk \& Miles, 2019; Gonzalez-Uribe \& Leatherbee, 2018) that can enable recovery and resiliency. Accelerators are fixed-term, cohort-based programs that offer high-growth start-ups seed capital, mentorship, networking, entrepreneurship schooling, and entrepreneurial capital (Clarysse \& Yusubova, 2014; Cohen \& Hochberg, 2014; Hochberg, 2016). The first accelerator, namely Y Combinator, was established in Silicon Valley in 2005. This is considered the most successful accelerator in the world. The business acceleration phenomenon has since grown rapidly around the world, with well over 3,000 accelerators worldwide (Hochberg, 2016). While initial studies on the effects of acceleration programs show mixed conclusions (Hochberg, 2016), other studies point to their performance and effectiveness in achieving their objectives (Gonzalez-Uribe \& Leatherbee, 2018). Acceleration is a fairly new phenomena in several countries outside of the US; hence, there exists major differences among them (Goswami, Mitchell \& Bhagavatula, 2018; Uhm, Sung \& Park, 2018). The general consensus is that accelerators play an important role in supporting promising start-ups (Chan, Patel \& Phan, 2020), and are vital actors in the entrepreneurial ecosystem of many countries. However, their role of will undoubtedly need to undergo changes to serve the evolving needs of startups in these challenging times ahead.
AcceleratorshavegrownsignificantlyinSouthAmerica, particularly over the past five years. According to Crunchbase (2020a), there are over 74 active accelerators located in South America (111 in Latin America). Some are local accelerators, often supported by governments. Others are subsidiaries of other nations' accelerators, in particular from the US but also from Europe. Examples of successful accelerators include Start-Up Chili considered the "spark that ignited Latin America's start-up ecosystem" (Techcrunch, 2018) and the leading accelerator in Latin America. InovAtiva in Brazil, HubBOG Accelerator in Colombia and several others add to the list. Yet, the literature has primarily focused on accelerators from the US and Europe (Cohen, Fehder, Hochberg \& Murray, 2019; Drori \& Wright, 2018). Despite government-backed innovation programs, foreign capital funding flowing to South American startups, and the involvement of foreign accelerators with these start-ups, studies of South American accelerators are noticeably scarce. Furthermore, newer models of accelerators are emerging in South America, studies which would enrich the evolving literature on accelerators. US-based accelerators, such as Techstars, have been accepting Latin American start-ups for nearly a decade now. The US experience helps start-ups to succeed. Currently, 500 Startups is the only major US accelerator with a physical presence in South America. Several South American university-based accelerators exist. However, notwithstanding the growing importance of accelerators in South America, few studies have analysed such an emerging phenomenon, and none have analysed the impacts of the COVID19 pandemic on them. The newness of COVID-19, the sparse post-COVID-19 world literature and the dearth of accelerator studies addressing the South American context are gaps that we are attempting to fill. Hence, our goal is to explore how South American accelerators need to evolve in a post-COVID-19 world.

The aim of this paper is to propose a Post-COVID-19 accelerator model, with a focus on applicability to the South American entrepreneurship ecosystem context. In doing so, we contribute to the literature in three ways: First, we contribute to the nascent literature on accelerators, with an emphasis on the South American accelerator landscape. Second, we investigate the evolving role that business accelerators will have in a post-COVID-19 world. Third, we propose a Post-COVID-19 Accelerator 
Model for researchers, accelerator managers, policymakers and entrepreneurs in order to navigate these turbulent times, along with future research directions.

\section{Taxonomy \& Characteristics of Accelerators}

The distinction between business accelerators and incubators is fluid (Drori \& Wright, 2018). Both concepts have evolved over time, but a general definitional consensus has emerged. Business incubators have gone through several iterations or generations since their inception in the US in the late 1950s followed by a slow diffusion worldwide in the 1960s and 1970s (Hackett \& Dilts, 2004). Generally, incubators provide office space, shared services, and on-site management with some business support functions, and a supportive environment (Bruneel, Ratinho, Clarysse \& Groen, 2012; Mian, Lamine \& Fayolle, 2016). The newer generations of incubators place a stronger emphasis on supporting their start-up firms with direct access to capital and specialized services to speed up the commercialization of their novel products or services (Clarysse \& Yusubova, 2014; Grimaldi \& Grandi, 2005).

Accelerators, also called seed accelerators or accelerator programs, emerged in the early 2000 s, in what some consider a new generation of the business incubation model (Pauwels, Clarysse, Wright \& Van Hove, 2016; Wise \& Valliere 2014). Others argue that this new innovation intermediary differs considerably from incubators (Cohen \& Hochberg, 2014). The most commonly accepted definition of accelerators is "a fixed-term, cohort-based program, including mentorship and educational components, that culminates in a public pitch event or demo-day" (Cohen \& Hochberg, 2014, p. 4). As the name implies, accelerators have a more explicit focus on accelerating the growth of firms than an incubator (Isabelle, 2013). Accelerators provide pre-seed investment in exchange for equity (Pauwels et al., 2016), coworking space, entrepreneurship education, and mentorship in a fast-paced environment (Chan et al., 2020; Drori \& Wright, 2018) and facilitate connections with potential investors, within a specific time period, typically three to six months (Cohen et al., 2019). Investors often act as mentors to accelerated start-ups (Hochberg, 2016). A key distinction relates to their legal status. Most accelerators are for-profit organizations designed to bring about a return on investment to their shareholders, while incubators are generally not-for-profit organizations (Isabelle, 2013). In effect, selection criteria of accelerators are often highly competitive. For instance, Techstars, a private accelerator and a model among accelerators, only accept a dozen out of thousands of applicants (Cohen et al., 2019). The first accelerator, Y Combinator, emerged in the US in 2005. Its model has since been replicated worldwide. A key driver in the emergence and proliferation of accelerators is the drastic lower costs of starting a new venture. Thus, a small seed investment along with assistance from accelerators can really provide meaningful results to start-ups compared to even a decade ago (Hochberg, 2016).

In practice, the terms incubator and accelerator are often used interchangeably as these organizations tend to operate in overlapping domains (Isabelle, 2013). A number of hybrid programs combine aspects of both incubators and accelerators. A case in point, of the nearly 700 US based organizations identified as accelerators in 2016, fewer than one-third actually met Cohen \& Hochberg's (2014) definition (Hathaway, 2016). UBI (2020) classifies accelerators into four categories: university accelerators, public accelerators, which derive their business objectives primarily from one or more public entities, private accelerators, that develops their business objectives independently and finances their own operations, and corporate accelerators that derive their business objectives primarily from one or more for-profit corporations. Well-known examples of corporate accelerators include Microsoft Ventures Accelerator and AT\&T Aspire Accelerator in the U.S. Our focus is on private and public accelerators.

Accelerators operate under a broad range of strategic objectives. Such objectives include growing start-ups, technology transfer, commercialization, clusters and developing entrepreneurship, as well as capitalizing on investment and technological opportunities (Drori \& Wright, 2018). Depending on the main strategic objective, the configuration, governance, services provided, as well as sources of funding of the accelerators will vary. Further, models are evolving in order to adapt to the external environment under which accelerators are operating (Clarysse \& Yusubova, 2014).

Research on accelerators fall into two major categories: conceptual description of accelerators and empirical accelerator impact studies (Hochberg, 2016). For instance, recent research on accelerators to date has examined taxonomy to define characteristics and features of accelerators (Cohen \& Hochberg, 2014; Cohen et al., 2019; Del Sarto, Marullo \& Di Minin, 2018; Isabelle, 2013; Mian et al., 2016; Pauwels et al., 2016; Wright, 2017), impacts on startups (Del Sarto, Isabelle \& Di Minin et al., 2020; Kim \& Wagman, 2014; Battistella, De Toni \& Pessot, 2017; Wise \& Valliere, 2014), and on ecosystems (Frimodig\&Trokkeli,2017; Wright, Siegel\&Mustar,2017). Another research stream is that of accelerators as an open innovation tool (Jackson \& Richtr, 2017; Kanbach \& Stubner, 2016). 


\section{Impact and Performance of Accelerators on Start-ups and Ecosystems}

Differences among accelerators appear to explain meaningful differences in performance among member startups (Chan et al., 2020). On that point, Hochberg (2016) highlights the need for regional ecosystem-level analysis of the effects of accelerator programs. The field of research on accelerators is recent compared to that of incubators. Hence, studies on the impacts of accelerators on firm survival and their success are sparse (Cohen et al., 2019; Del Sarto et al., 2020). The situation is particularly so in the context of accelerators in South America, to the exception of Gonzalez-Uribe \& Leatherbee (2018) who investigated the impacts of basic versus additional entrepreneurship services of Start-Up Chile on new venture performance. Furthermore, the results are mostly mixed, mainly because a common business model among accelerators is assumed (Cohen et al., 2019). Consequently, differences among accelerators, or "accelerator morphology" (Chan et al., 2020) are neglected. In addition, Mian et al., (2016) raise the need to apply consistent theoretical lens. The lack of studies contrasting accelerated ventures to a control group of non-accelerated ventures remain a common gap for both incubators and accelerators (Pauwels et al., 2016).

In spite of these issues, research points to the positive impacts of accelerators on the success of start-ups (Del Sarto et al., 2020). For instance, studies suggest that the cohort nature of accelerator programs allows efficiency in the provision of support from providers such as investors (Cohen et al., 2019). Other studies have found that accelerators increase the ability of accelerated start-ups to receive subsequent funding (Radojevic-Kelley \& Hoffman, 2012), the acquisition of new knowledge (Battistella et al., 2017; Hallen, Bingham \& Cohen, 2016) and start-up valuation (Kim \& Wangman, 2014; Smith \& Hannigam, 2015). In that vein, venture capitalists view accelerators as deal sorters and aggregators. Since accelerators have rigorous selection criteria and demo days, investors are given the opportunity to observe several start-ups at once (Hockberg, 2016). In summary, despite positive results, there remain important questions about the effect of the average accelerator program on start-ups. Yet, despite the absence of concrete empirical validation, entrepreneurs arewillingandeagertoparticipateinsuchprogramstoimprove their performance (Cohen et al., 2019). These findings point to the need for expanded understanding of this innovation intermediary. However, the newness of the acceleration phenomenon, limited data, an absence of a clear definitional consensus, and significant heterogeneity among accelerators and regional ecosystems impede progress on performance studies (Hochberg, 2016; Isabelle, 2013; 2014).
Few studies have targeted accelerators based in South America to the notable exception of the literature on Start-Up Chile (e.g., Carmel \& Káganer, 2014; Carmel \& Richman, 2013; Gonzalez-Uribe \& Leatherbee, 2018; Leatherbee \& Gonzalez-Uribe, 2017; Vandeweghe \& Fu, 2018). We seek to contribute to this growing body of literature.

\section{Accelerator Landscape in South America}

Comprehensive data on the accelerator scene in South America is challenging to come by. According to Crunchbase (2020a), of the 74 accelerators in South America, 54 are located in Brazil. While there is a growing body of literature on accelerators in the more advanced economies, it is significantly under-researched in South America. In this section, we briefly review a selection of the largest South American economies and their accelerator landscapes by drawing on the academic literature, seminal papers, specialized websites, and institutional reports.

In Brazil, fintech, education, e-commerce, shipping and logistics, medical, and $\mathrm{B} 2 \mathrm{~B}$ service industries tend to be the focal industries of their accelerators. Accelerators include Darwin Startups, Sevna Startups, Spin Aceleradora de Startups, Rede Entropia and Syndreams Aceleradora. For example, WOW Aceleradora offers an accelerated program that combines capital, networking, mentoring and training. The accelerator duration is also 24 weeks. InovAtiva, a federal government-sponsored acceleration program, provides equity-free funding. Others have since evolved their business model; for example, ACE Startups, a Brazilian Seed stage Venture Capital (VC), was formerly an accelerator and was three times best Latin American accelerator (Crunchbase, 2020a).

Argentina boasts some 13 accelerator programs in e-commerce, IT, food tech, agritech, mobile and digital media. As an example, Glocal is an accelerator for start-ups and mid-sized firms in the agribusiness industry. It offers access to Glocal's contact network that has long-standing relationships with major industry players. Such contacts include farmers, brokers, distributors, exporters, traders, insurance companies, futures exchange, and other associations that connect producers or other agents of the agribusiness chain (Glocal, 2020).

In Colombia, agriculture and nutrition, creative industries, sports and peace, as well as entrepreneurship and peace are the accelerators' areas of focus. TIC Colombia, (Talent and Innovation Competition of the Americas) is a regional hub of TIC Americas (in Latin America and the Caribbean). Entrepreneurs have access to training opportunities, investors and new markets, and are invited to participate in conferences and international competitions (TIC Americas, 2020). Other accelerators include Colombia Startup, HugBog and Macondolab. 
Start-Up Chile, founded in 2010 by the Chilean government is considered the best accelerator in Latin America and one of the top public accelerators in the world. In fact, Chile has been dubbed "Chilecon Valley' for its accelerators (WEF, 2018). Start-Up Chile is a public business accelerator for start-ups aiming to go global. It has a large portfolio of up to 160 start-ups per year. The accelerator provides on-site support, early stage venture, grants, private equity and seed investments. The accelerator duration is 24 weeks and the program ends with a Demo Day. Given its global mandate, it offers access to local and international networks of mentors and investors. In addition, the accelerator provides a one year working visa and a soft landing for foreign startups accepted in the program (Start-Up Chile, 2020a). To date, Start-Up Chile has accelerated over 1600 companies from 85 different countries. Given its success, others around the globe have replicated the program, such as Start-Up Brasil and Start-Up Peru. Besides Start-Up Chile, the country boasts some 20 other incubators and accelerators. Start-Up Chile is the topic of several academic studies.

In Bolivia, the Founder Institute, a pre-seed start-up accelerator located in over 185 cities in six continents, has launched a chapter: Bolivia Founder Institute (Founder Institute, 2020). Founder Institute also has a presence in Brazil, Argentina, Chile, Peru, Uruguay and Colombia.

\section{Accelerator Processes}

Understanding how accelerators must evolve to help start-ups in a post-COVID-19 world will benefit from an overview of typical processes and services preCOVID-19. As for business incubators, the general consensus is that no one-model can fit all cultural contexts, economic situations and ecosystems (Machado, da Silva, Borba \& Catapan, 2015). However, most accelerators share similarities as they have essentially reproduced the same formula. In essence, the process starts by an open application approach. Applicants are start-up teams, growth-oriented ventures aiming to rapidly scale their business models. Using a cohort-based approach, accelerators select ventures and invest, generally in exchange for equity at the pre-seed or seed stage. In return, they provide resources, education, mentoring and access to industry networks, in a time-bound commitment (Richter, Jackson \& Schildhauer, 2018). Table 1 provides a brief summary of the top accelerator in the U.S., Y Combinator, one of the very first accelerators, with the top accelerator in South America, Start-Up Chile.

A unique and distinct feature of $\mathrm{Y}$ Combinator is that although the program requires accepted start-ups to relocate to the Bay Area for the three-month run, it does not offer coworking spaces. However, around the world, countries replicating the Y Combinator model have opted to offer shared office space.

\section{Emerging Trends in the Fast-moving Acceleration Landscape}

The entrepreneurship ecosystem is a fast-moving landscape with incubators morphing into accelerators or adding acceleration programs to their arsenal of services. Furthermore, accelerators are cropping up everywhere to provide investment, mentorship and support to help start-ups grow. There is also evidence of business model pivots taking place. For instance, Wayra, a Madrid-based accelerator, is changing its business model toward a VC

Table 1. Comparison of top US and Chile accelerators: Y Combinator \& Start-Up Chile

\begin{tabular}{lcc}
\hline & Y Combinator (US) & Start-Up Chile \\
\hline Legal status & Private & Public \\
Cohort based & Yes, 2/year & Yes, 2/year \\
Equity-free cash infusion & Seed funding for 7\% equity & Yes, equity-free \\
Acceptance rate & $<3 \%$ & 5 to $10 \%$ \\
Shared office space & No & Yes \\
Advice \& mentorship & Yes & Yes, entrepreneurship school to selected \\
Regular meetings with program staff, program peers, industry experts & Yes & Yes \\
Networking & Yes & Yes \\
Working Visa \& Soft Landing & US visa rules & Yes \\
Duration & 3 months & 6 months \\
Demo Day & Yes & Yes \\
\hline
\end{tabular}


fund for more mature, later-stages start-ups and concentrating its operation in Colombia, Brazil and Argentina. In South America, Wayra will close its facilities in Chile, Peru and Venezuela (Empresas, 2020).

Among other observed trends, accelerators are refining their strategies and moving away from offering general support to start-ups from any industry toward an industry-specific focus, or "vertically specialized accelerators" (Hochberg, 2016). For instance, accelerators now offer specialized programs with a focus on niche industries such as agtech, fintech and social impact. Examples are The Yield Lab, Argentine agtech accelerator, and Bci Labs, a Chilean accelerator focused on fintech (Techcrunch, 2018). Still, software and services start-ups remain a focus of choice (Hochberg, 2016). There are also accelerators whose mandate is to support women entrepreneurs. One such example is the S Factory in Chile, a pre-acceleration program under Start-Up Chile for start-ups led by female founders (StartUp Chile, 2020b). Furthermore, accelerators are forging partnerships with investors and other organizations within and outside of their locality and are becoming progressively more global. Accelerators are also investing in high-impact early-stage companies all around the world. Accelerators are now considered a top mechanism for start-ups in South (and Latin) America to obtain funding and internationalize (Techcrunch, 2018).

Following this overview of the accelerator phenomenon situation in South America and the general modus operandi of accelerators, we will now explore expected short-term and longer-term consequences of the current COVID-19 pandemic globally, on South America, start-ups and accelerators.

\section{Impacts of COVID-19}

\section{Global Impacts}

Without a doubt, COVID-19, which originated in Wuhan city in China in December 2019 and spread worldwide, has resulted in a significant global shock. The pandemic is not over yet, and successive waves of infection are feared. The crisis has disrupted every area of life. The geopolitical implications of the pandemic are still unfolding. On the economic front, owing to our strongly connected and integrated world, global financial markets have tanked and volatility has soared. In its preliminary assessment, the World Bank (2020) predicts that gross domestic product will fall by 2 to $4 \%$ depending on the different regions of the world. The biggest negative impacts are the output of domestic services affected by the pandemic, as well as trade, the hospital- ity industry, sports industry and global tourist services (Ozili \& Arun, 2020). Safety protocols and public health measures, travels restrictions and severe lockdowns have led to a decrease in consumption, cancellation of events and public gatherings, closures of manufacturing sites, layoffs and production interruptions. All sectors have been affected, particularly the service sectors given that the lost output will not be recovered post pandemic. Global value chains have been severely disrupted, generating spillover effects throughout networks of suppliers. The world is experiencing a simultaneous destruction of demand and supply (Fernandes, 2020). Every day, industries in peril and bankruptcies fill the news. Governments around the world have responded with various policy interventions to contain the spread of the virus, implement health measures and introduce support programs for industries, companies, and individuals (Hale, Petherick, Phillips \& Webster, 2020). It is believed that we have now entered a period of global recession, the scale of which is currently unknown (Sulkowski, 2020).

\section{COVID-19 and South America}

COVID-19 has reached South America a little later than other regions. By now though, every country in the continent has been affected, particularly Brazil and Peru. The economic impact of the pandemic on Brazil is expected to decrease its GDP by 3 to 7\% (Fernandes, 2020). The situation in South America is especially worrisome due to under-resourced public health systems. Moreover, the informal economy prevalent in the region means that the population affected by lockdowns and/or the disease cannot access government benefits (Kirby, 2020). As experienced by other countries hit by the virus, the impacts of COVID-19 include a reduction in international trade, falling commodity prices, lower demand for tourism services, and additionally, a drop in remittances sent home from workers abroad. Against this backdrop, unemployment and poverty will rise as the pandemic results in a severe contraction in economic activity (UN, 2020).

According to Export Development Canada (EDC, 2020), sectors highly affected by COVID-19 in South America include retail, airlines, tourism, and entertainment. IT firms and companies producing and transporting essential goods are less affected, at least for now. SMEs, micro businesses and highly leveraged businesses are most affected due to their vulnerable financial situations. Uncertainties related to how long the pandemic will last, the overall perception that the recession will be severe, the fear of insolvency for small businesses, and the risks of social unrest are compounding factors creating a very challenging business environment. 


\section{Impacts of COVID-19 On Start-ups}

The business landscape for start-ups will definitively be more challenging in a post-COVID-19 world. The academic literature on the impacts of COVID-19 on startups, including their survival and recovery, is nascent. There are however, glimpses of opportunities and growth. We now derive the consequences of the impacts of the pandemic raised above for South American start-ups.

Start-ups, and in particular those related to industries severely affected by the COVID-19 crisis, will necessitate a thoughtful assessment of their business models, products and services. Long term, if not permanently, consumer behavioural changes and drastic decrease in consumption are expected in South America, as well as elsewhere. Current COVID-19-related rules and regulations might stay in one form or another. New regulations might restrict the operating flexibility of start-ups. International trade, be it sourcing input or selling to global markets, will continue to be deeply affected by factors such as disruptions in global value chains, and an accelerated move away from globalization and toward a more regionalized world economy. Start-ups may need to explore alternatives in every area of operation such as raw materials and supplier chain channels (Nseobot et al., 2020).

Challenges of start-ups operating in South America and elsewhere are multifaceted. In the best of times, startups do face enormous challenges to validate and scale their business models, and to overcome liabilities of newness and smallness (Stinchcombe, 1965). The expected severe global recession will negatively impact revenues and add pressure to reduce operating costs. Hence, postCOVID-19, more start-ups are likely to fail. Others might be able to pivot their original idea toward potential solutions to the COVID-19 crisis and opportunities created by the pandemic and experience growth as a result. Startups do not have the resources to undertake costly market research and be cognizant of the fast-evolving business and regulatory environment. Another crucial factor relates to the availability of funding. It is expected that venture capital (VC) might decrease significantly in South America, as evidenced in countries affected early by COVID19. Further, investors might pull back from their usual areas of focus and redirect their interest in more promising areas such as healthcare investments, wireless rapid health assessment and monitoring devices. Investors and VCs are likely to become more risk adverse. Under this high level of uncertainties at so many levels, business planning using a causal entrepreneurship decision-making logic (Mintzberg, 1978) will be ineffective.

Cultural aspects will continue to influence business and consumer behaviours in a post-COVID-19 world. While connectivity and smartphone adoption are high in South America, the South American culture values relations and face-to-face business interactions. This translates into a weaker confidence in digital solutions. Hence, the business and societal changes required to integrate new norms such as working remotely, no-contact solutions, and social distancing, will be quite profound (Crunchbase, 2020b). These changes occurring in the business landscape due to the pandemic coupled with South American cultural aspects and customer behaviours will impact the way in which start-up accelerators need to operate in the future. In the next section we integrate this review into a model to support the evolution of accelerators in a postCOVID-19 world to effectively support the recovery and resiliency of their start-up portfolio.

\section{Proposed Post-COVID-19 Accelerator Model}

It is imperative that accelerators anticipate and prepare for long-lasting changes brought upon by the pandemic. Here, we elaborate on the modifications which we believe accelerators will need to embark upon to remain relevant, innovative and sustainable. Specifically, we have identified four areas (i.e. macro environment, startups, accelerator processes, and accelerator services) that COVID-19 has had an impact on. For each of these areas, we propose strategies that accelerators should adopt now to ride out the pandemic and adapt to the post-pandemic business landscape. We argue that this new model will help accelerators reach expected outcomes considered critical to economic competitiveness, such as increased start-up activity and VC funding, employment, particularly in science, technology, engineering, math (STEM), and regional economic development (Hochberg, 2016). It is fair to say that in a post-COVID-19 world, governments will face enormous deficits, hence, they will be constrained in the selection of the best investments to restart their economies. Arguably, accelerators with a strong track record, operating in regions exhibiting strong and synergistic entrepreneurship ecosystem actors will be in a favourable position to be funded and to support their government's goals of restarting their economy.

A three-step COVID-19 approach, applied by many organizations, is also applicable to accelerators. The steps are: rapid response, recovery, and resilience (OECD, 2020). Around the world, accelerators have already gone through the first step of rapid response as they needed to quickly adapt their operations and processes to abide by new rules such as social distancing and health guidelines. For instance, some accelerators have postponed their next round of start-ups and application deadlines. Others have either cancelled or moved their Demo Days 
online. Most accelerators have moved the interactions among entrepreneurs and mentors by offering video conference calls, online resources and introduced new ways to work. Among these news ways is working from home, which has now become a popular WFH acronym. Some accelerators are providing recovery funding to support their start-ups. Others have taken advantage of government funding or use their own funds to fast-track start-up activities toward efforts related to COVID-19 solutions. Finally, some accelerators have announced the launch of specialized cohorts actively working on COVID-19 support and recovery solutions. We focus on the second and third steps of this framework, recovery and resilience.

Accelerators will need to revisit their business models to support their own recovery and that of their start-up portfolio, as well as strengthen resiliency in a post-COVID-19 world. We label this new model the PostCOVID-19 World Accelerator Model. Figure 1 illustrates our model.

We now explore the components of the proposed PCW Accelerator Model with an emphasis on South America. Drawing from the literature on accelerators and investigating the far-reaching impacts that the pandemic will have on start-ups and businesses in general, we identify four critical areas of impacts from the pandemic and recommend strategies that accelerators should implement to be successful and resilient in a post-COVID-19 world.

\section{Macro Environment}

On the macro environment side, governments worldwide are implementing measures to support businesses and enacting new rules and regulations. This two-fold action is designed to protect the population against the COVID-
19 virus and attempt to decrease the economic shock by slowly reopening their economy.

In South America, policy responses have been uneven. South American start-ups and small businesses are suffering from cratering demand, financially burdened households, falling exports, and lost income from tourism. Widespread bankruptcies are expected without government intervention. Compounding the situation, South America has hardly recovered from the 2008 global financial crisis, hence a regional coordinated response to enable fiscal resources is needed (WEF, 2020). Given these turbulent environments, we suggest that accelerators adopt a stronger advocacy role with governments. We concur with Goswami et al. (2018) that accelerators are important entrepreneurial ecosystem intermediaries. For example, accelerators, with their knowledge of their local entrepreneurship ecosystem and actors, could weigh in on proposed changes to government priorities and assist the government in developing long-term entrepreneurship policy measures to support rapid recovery and growth (Kuckertz et al., 2020). This is particularly critical as most government programs, in South America and elsewhere, have focused on established firms and specific industry sectors rather than start-ups. Figure 2 displays the recently announced financial packages to support business and households in Latin America.

The pandemic has dealt a blow to the emergence of South America's vibrant homegrown start-up ecosystem, particularly with VC deals (TechCrunch, 2020). Hence, accelerators' sources of funding are expected to decrease. Private accelerators can expect that their funders will invest less, may change their investment focus, and might become more risk adverse. Public accelerators risk

Figure 1. Post-COVID-19 World Accelerator Model (PCW Accelerator Model)

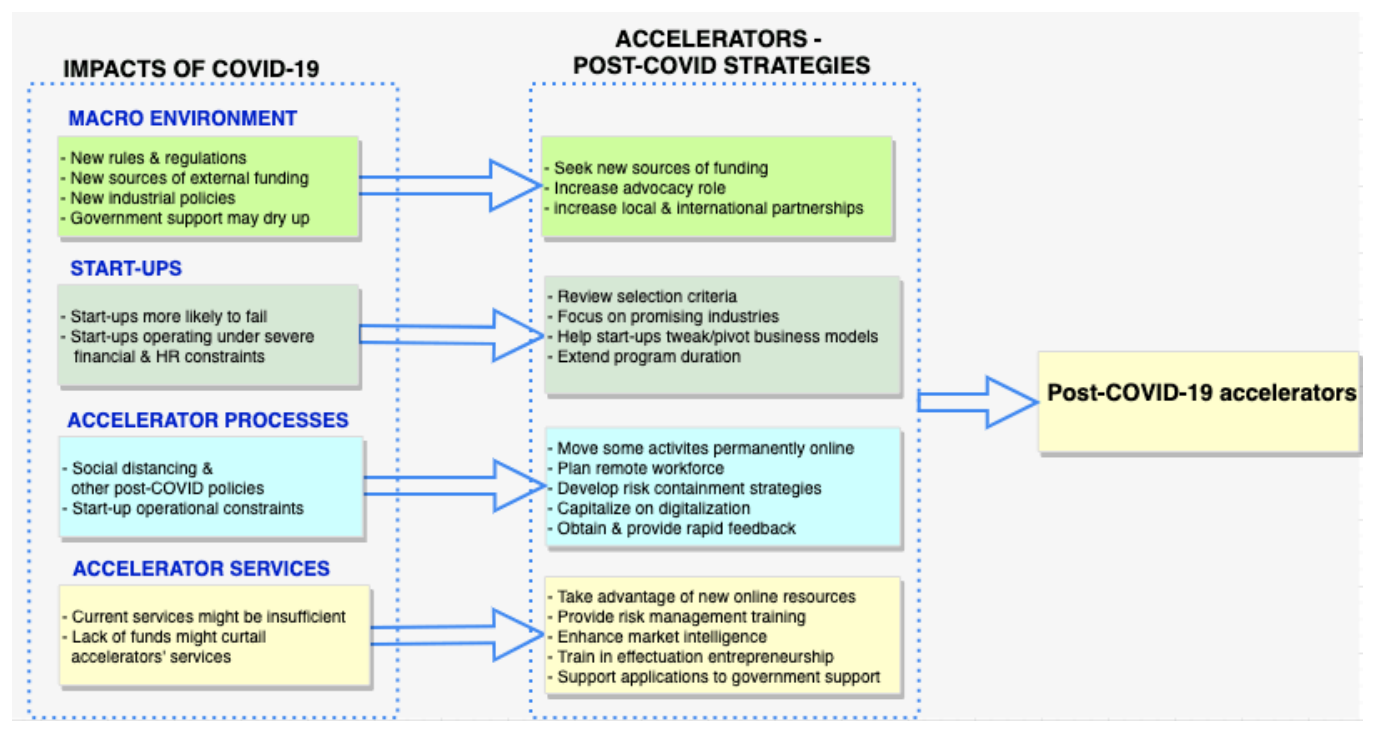




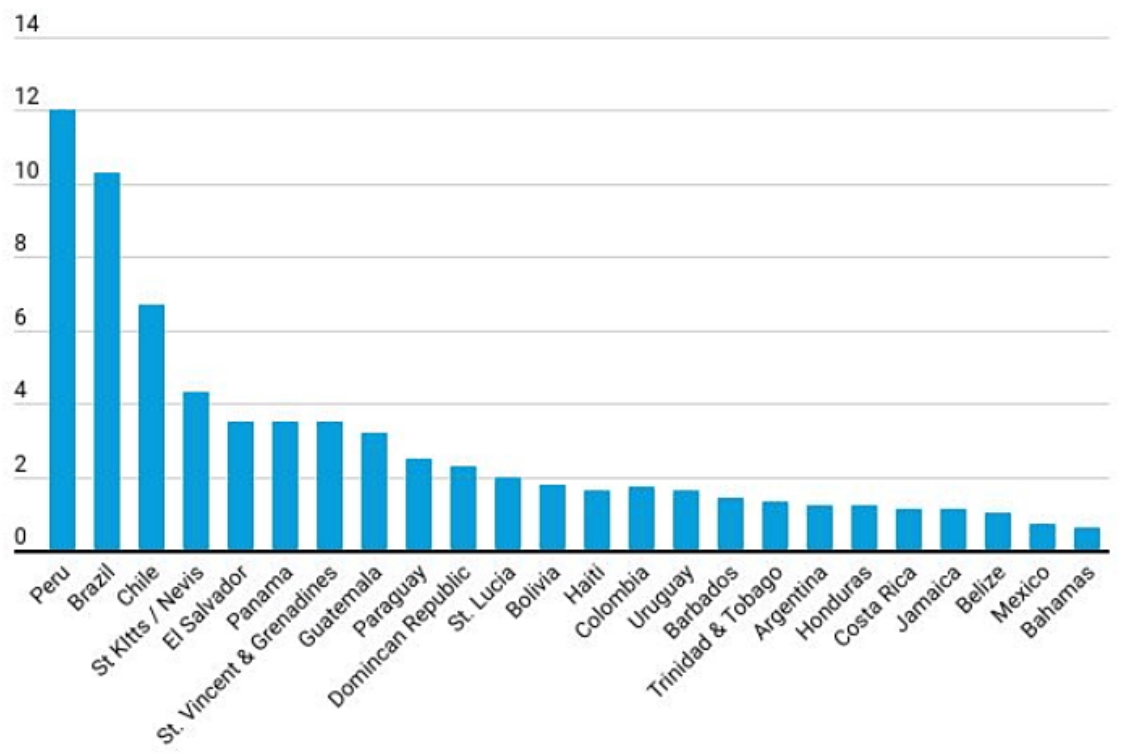

finding themselves competing even more with others for government support in a post-COVID-19 world. New funding strategies might be called for, including seeking entirely new sources of funding.

We expect that local and international partnerships will increase; for example, the Bill \& Melinda gates foundation recently formed a partnership with Wellcome and Mastercard to launch a novel COVID-19 Therapeutics Accelerator initiative (Gates Foundation, 2020). Several other partnerships have emerged since the beginning of the pandemic. In that vein, South American accelerators might seek international partnerships with US based accelerators, or with regional or foreign early-stage venture capital firms to reduce costs and create synergies. Partnerships that can enable the operationalization of effective solutions to emerging trends post-COVID-19 should be especially sought after. For example, accelerators could strike partnerships with organizations that can support the internationalization of accelerators' start-up portfolio since domestic consumer and industrial demands will be greatly weakened. Hence, start-ups will need support and guidance to successfully diversify their geographical markets. Taken together, these diverse new forms of partnerships may result in vastly different accelerator business models, opening up new areas of research.

\section{Start-ups}

The huge unemployment of South Americans might push more people into entrepreneurship. Yet, the economic consequences of the current global pandemic significantly increase the probability of potential failure for start-ups. Accordingly, South American accelerators might consider reviewing their selection criteria and employing a robust selection approach such as the Real-Win-Worth framework (Day, 2007), referring to Is it real? Can it win? Is it worth doing? which Yin \& Luo (2018) have tested with managers of a Singaporebased accelerator. In particular, accelerators will have to pay close attention to the industries in which startups are operating as part of their revised selection criteria. For instance, start-ups operating in the travel and tourism industry will not be attractive since this industry is expected to face a long and uphill battle to recovery. Conversely, accelerators might consider adjusting their selection criteria for promising start-ups that are working on innovative solutions to the pandemic. As an example, start-ups developing healthcare IT solutions, which might normally be outside the focus of accelerators, could be considered. Other potential opportunities include personal protective equipment, home deliveries, online services, home virtual entertainment and other unexpected opportunities discovered from the pandemic. The pandemic might in fact accelerate the development and successful commercialization of such technologies like drones and self-driving cars for commercial delivery (The Engineer, 2020).

A notable area expected to bring about significant opportunities in a post-COVID-19 world is digitalization for improved value creation and appropriation, such as cloud-enabled IT infrastructure, enhance cyber security, expanding the Internet of Things to $\mathrm{B} 2 \mathrm{C}$ operations, 
artificial intelligence (AI) and machine learning, robotic process automation, and blockchain applications (Kohtamäki, Parida, Patel \& Gebauer, 2020). These fields offer opportunities in data tracking, data protection, data infrastructure, and testing. The buildout of 5G is expected to slow down in the short term but possibly accelerate through government funding owing to the expected value of high-speed connectivity and economic potential. 5G deployments are already underway in several South American countries such as Brazil, Argentina, Colombia and Chile. However, there are technological, financial and policy issues involved with $5 \mathrm{G}$, particularly for low-and middle-income countries (Forge \& Vu, 2020). In all, creativity, innovation and resiliency will result in countless opportunities.

Although new opportunities post-COVID-19 might appear promising, accelerators should thoroughly investigate the business models of current and future cohorts of start-ups to reassess the viability and scalability postCOVID-19 and support start-ups to modify or pivot as needed. Thoroughly evaluating every single area of a business model, particularly value propositions, and testing business ideas will become crucial (Bland \& Osterwalder, 2019; Osterwalder, Pigneur, Bernarda \& Smith, 2014; Osterwalder \& Pigneur, 2010). In addition, accelerators need to help start-ups assess the attractiveness of the industry in which they are operating, using for instance an updated Porter's Five Forces framework (Isabelle, Horak, McKinnon \& Palumbo, 2020). As every aspect of the entrepreneurship ecosystem is affected, start-ups might take longer to reach Demo Day readiness. Thus, accelerators might consider extending the duration of their programs.

\section{Accelerator Processes}

As remarked by Bliemel et al. (2019), accelerators are a relatively recent addition to the entrepreneurship ecosystem and hence, are constantly evolving. With social distancing and other post-COVID-19 policies, accelerators had to and will continue to modify their business processes. More of their activities, including mentoring and meetings, went online, and accelerator staff have begun to work remotely. Demo Days have been pushed back, cancelled or went online. Cohort applications have been postponed and selection mechanisms, such as interviews, have been modified. With the pandemic lasting longer than originally expected, accelerators will need to develop longer term containment strategies. Even elite programs like YC might be forced to go entirely remote. However, online processes offer some advantages as well, such as time saving and more introductions between investors and founders. Furthermore, accelerators could accept more foreign start-ups in remote programs, since a core objective of several accelerators is to support transnational entrepreneurs (Brown, Mawson, Lee \& Peterson, 2019; Gonzalez-Uribe \& Leatherbee, 2017). In practice though, start-up entrepreneurs would much rather interact with mentors, investors and movers and shakers of the tech world in person (Wired, 2020). With more processes moving online, accelerator managers will need to foster close collaboration between program managers, instructors, mentors and entrepreneurs. Under these new operating processes, differentiators among South American accelerators will be crucially important to attract, on the one hand, funding, and on the other hand, entrepreneurs. In a post-COVID-19 world, accelerators will need to innovate their business models by validating assumptions around proposed changes to processes, obtaining rapid feedback, tweaking, implementing and reassessing changes. It will be vital to seek prompt feedback from their various stakeholders.

\section{Accelerator Services}

Likewise, the pandemic will oblige accelerators to revamp their offerings. Several mitigation mechanisms can be considered: a panoply of valuable online resources, several free, have become available during the pandemic. These include guides, tools, software, training programs, among others. South American accelerator managers could sift through these resources and identify the most relevant for their portfolio of start-ups. Another mechanism involves enhanced training. Building on prior research of entrepreneurial crisis management, accelerators could offer crisis and risk management training to foster resilience and minimize the impacts of the pandemic (Kuckertz et al., 2020). Moreover, accelerators can play a key role in developing dynamic capabilities of their start-ups (Teece, 2012), in particular sensing the market to identify opportunities from an enhanced understanding of customer problems and needs (García-Ochoa, 2020).

In these highly turbulent times, innovative start-ups will need to rely on flexible and relatively recent theories in entrepreneurship research such as effectuation logic (Sarasvathy, 2001), which emphasizes sense-making, taking into account resource limitations. Effectual logic is a non-predictive entrepreneurship strategy used when the future is unpredictable and goals are undefined. By comparison, causal logic, the traditional approach to entrepreneurship, assumes a predictable future and predefined goals (Fisher, 2012; Mintzberg, 1978). Thus, accelerators should consider training entrepreneurs in effectuation logic and related approaches such as bricolage (Baker \& 
Nelson, 2005), an improvisational approach to resources that enables entrepreneurs to achieve success by reconfiguring their existing means. Furthermore, these two key entrepreneurial approaches, effectuation and bricolage, are considered effective in the internationalization process of small firms (Karami, Wooliscroft \& McNeill, 2019), which will become even more critical in a postCOVID-19 world.

Prior research has demonstrated the positive influence of effectuation on entrepreneurial orientation (EO) and innovative firm performance (Mthanti \& Urban, 2014). Entrepreneurial orientation (EO) is defined as an individual's attitude toward engaging in entrepreneurial activities. The three dimensions of EO are innovation, proactiveness, and risk taking (Lumpkin \& Dess, 1996). The concept encapsulates decision-making styles, methods and practices that help entrepreneurs act in an entrepreneurial manner by innovating, taking risks, and proactively pursuing market opportunities (Nseobot et al., 2020). In a post-COVID-19 world, a strong EO will be required since the accelerated adoption of innovative technologies to conduct business is fast becoming the norm, as well as to identify and capitalize on emerging market opportunities. Therefore, we suggest that accelerators incorporate an assessment of the $\mathrm{EO}$ of potential start-ups in their selection criteria.

Lastly, most government stimulus packages include funding to accelerate the development of COVID-19 related solutions. Proactive accelerator managers should monitor government policy measures, helping their start-up portfolio to take advantage of appropriate funding.

\section{Conclusion}

This study aims to bring about a rapid response to the fast-evolving role that business accelerators are called to play during and post-COVID-19. Our research provides both theoretical and managerial implications. First, we contribute to the literature by investigating relevant streams of literature related to accelerators, entrepreneurship theories, and entrepreneurial orientation to the pandemic situation. In particular, we highlighted that changes in the cultural foundation of a society due to the pandemic crisis may impact the entrepreneurial orientation (Lee \& Peterson, 2000), influencing the decision of entrepreneurs to participate in accelerator programs. Moreover, we advance the understanding of the nascent literature on accelerators (Cohen et al., 2019; Del Sarto et al., 2020; Isabelle, 2013), adding to this literature how accelerators should be implemented in the South American context and in a post-COVID-19 world. Building on prior research, we developed a forward-looking model, the Post-COVID-19 Accelerator Model, that academic researchers can build on to further the field. We believe that the results from this study can be generalized to developed as well as other low- and middleincome countries.

As for managerial implications from our study, we advise accelerator managers in South America to apply our PCW Accelerator Model to evolve their business models toward long term sustainability and relevance in these highly turbulent and uncertain times. We also believe that our model is a valuable tool to help meaningfully engage accelerators' stakeholders. On the policy front, recent empirical evidence points to the value of policymakers to invest in business accelerations for regional economic development and to stimulate entrepreneurship (Chan et al., 2020; Cohen et al., 2019). Hence, our study, which is among the first to study the South American accelerator COVID-19 context, provides guideposts for South American policymakers in their quest for the recovery and resilience of their economy. As for start-up entrepreneurs, the pandemic has greatly increased entrepreneurship challenges, and that will remain so post COVID-19. More than ever, entrepreneurs must ensure that their goals and objectives are aligned with those of the targeted accelerator without becoming overly dependent on the accelerator. Entrepreneurs must also pay close attention to the accelerators' selection and graduation policies, the nature and extent of services provided, which might be reduced or less efficient in a post-COVID-19 world, and assess the quality and availability of the network of partners (Isabelle, 2013).

Like most studies, the present one has limitations. The limitations are primarily due to the newness of COVID19, the sparse post-COVID-19 world literature, and the dearth of accelerator studies addressing the South American context. Therefore, many areas of the above research themes remain underexplored and provide directions for future investigation. A topic that is ripe for future research is that of virtual accelerators. We argue that the pandemic might accelerate the move toward virtual accelerators. This under researched area is clearly in need of deeper investigation given the drastic and rapid move to online business processes and services caused by the pandemic. The literature on corporate accelerators is another area worth exploring in a post-COVID-19 world since accelerators in South America and elsewhere might embrace this concept. Building on the business model innovation literature, new accelerator business models provide yet another area worthy of investigation. Finally, the financial constraints of governments and investors create even more impetuosity to explore the effects of accelerators on regional entrepreneurship ecosystems and entrepreneurial 
activity and capacity. This is of paramount importance in regions with less developed start-up infrastructure. These proposed research directions represent fertile areas of investigation, particularly for South America, owing to the relative newness of accelerators in the region.

\section{Acknowledgements}

The authors would like to express their gratitude to the two anonymous reviewers for their helpful comments and suggestions, and to the editor, José Rojas-Mendez for his kind consideration of our paper.

\section{References}

Baker, T., \& Nelson, R. E. (2005). Creating something from nothing: Resource construction through entrepreneurial Bricolage. Administrative Science Quarterly, 50(3), 329-366.

Battistella, C., De Toni, A.F., \& Pessot, E. (2017). Open accelerators for start-ups success: A case study. European Journal of Innovation Management, 20(1), 80111.

Bland, D.J., \& Osterwalder, A. (2019). Testing Business Ideas. JohnWiley\&Sons, Hoboken: NewJersey.

Bliemel, M., Flores, R., De Klerk, S., \& Miles, M.P. (2019). Accelerators as start-up infrastructure for entrepreneurial clusters. Entrepreneurship \& Regional Development, 31(1-2), 133-149.

Brown, R., Mawson, S., Lee, N., \& Peterson, L. (2019). Start-up factories, transnational entrepreneurs and entrepreneurial ecosystems: Unpacking the lure of startup accelerator programmes. European Planning Studies, 27(5), 885-904.

Bruneel, J., Ratinho, T., Clarysse, B., \& Groen, A. (2012). The evolution of business incubators: Comparing demand and supply of business incubation services across different incubator generations. Technovation, 32(2), 110-121.

Carmel, E., \& Káganer, E. (2014). Ayudarum: An Austrian crowdsourcing company in the Startup Chile accelerator program. Journal of Business Economics, 84(3), 469-478.

Carmel, E., \& Richman, J. (2013). Building international social capital at the Startup Chile accelerator. SSRN 2326003.

Chan, C.R., Patel, P.C., \& Phan, P.H. (2020). Do differences among accelerators explain differences in the performance of member ventures? Evidence from 117 accelerators in 22 countries. Strategic Entrepreneurship Journal, 14(2), 224-239.
Clarysse, B., \& Yusubova, A. (2014). Success factors of business accelerators. In Technology Business Incubation Mechanisms and Sustainable Regional Development.

Cohen, S., Fehder, D.C., Hochberg, Y.V., \& Murray, F. (2019). The design of startup accelerators. Research Policy, 48(7), 1781-1797.

Cohen, S., \& Hochberg, Y.V. (2014). Accelerating StartUps: The Seed Accelerator Phenomenon. SSRN 2418000.

Crunchbase. (2020a). South America Accelerators. https://www.crunchbase.com/hub/south-america-accelerators\#section-overview .

Crunchbase. (2020b). How the COVID crisis will evolve Latin America's technology adoption. https://news. crunchbase.com/news/how-the-covid-crisis-willevolve-latin-americas-technology-adoption/

Day, G.S. (2007). Closing the growth gap: Balancing big I and small i innovation. Market Science Institute Reports, (06-121).

Del Sarto, N., Marullo, C., \& Di Minin, A. (2018). Emerging actors within the innovation landscape: Systematic review on accelerators. ISPIM Conference Proceedings. Stockholm, Sweden. 17-20 June 2018.

Del Sarto, N., Isabelle, D.A., \& Di Minin, A. (2020). The role of accelerators in firm survival: An fsQCA analysis of Italian startups. Technovation, 90, 102102.

Drori, I., \& Wright, M. (2018). Accelerators: Characteristics, trends and the new entrepreneurial ecosystem. In Accelerators. Edward Elgar Publishing.

EDC (2020). Market insights: Monitoring the business impacts of COVID-19 on South America. https://www. edc.ca/en/blog/market-insights-south-america-covid

Empresas. (2020). Telefónica reestructura Wayra en Latam: cierra cuatro centros en varios paises. https:// www.lainformacion.com/empresas/telefonica-reestructura-wayra-latinoamerica-cierra-cuatro-oficinas/6514973/

Fernandes, N. (2020). Economic effects of coronavirus outbreak (COVID-19) on the world economy. SSRN 3557504.

Fisher, G. (2012). Effectuation, causation, and bricolage: A behavioural comparison of emerging theories in entrepreneurship research. Entrepreneurship Theory and Practice, 36(5), 1019-1051.

Forge, S., \& Vu, K. (2020). Forming a 5G strategy for developing countries: A note for policy makers. Telecommunications Policy, 44(7), 101975.

Founder Institute. (2020). It's time to build our post COVID-19 future. https://fi.co/s/santa_cruz_de_la_sierra/blog 
Frimodig, L., \& Torkkeli, M. (2017). Sources for success-new venture creation in seed and business accelerators. International Journal of Business Excellence, 12(4), 489-507.

García-Ochoa, C.P. (2020). How business accelerators foster startups' dynamic capabilities: A case study. ESIC Market. Economic \& Business Journal, 51(1), 19-43.

Gates Foundation. (2020). Bill \& Melinda Gates foundation, Wellcome, and Mastercard Launch initiative to speed development and access to therapies for COVID-19. https://www.gatesfoundation.org/Media-Center/Press-Releases/2020/03/COVID-19-Therapeutics-Accelerator

Glocal. (2020). Acceleration Program 2020, Agrifoodtech. http://www.glocalmanagers.com/en/

Gonzalez-Uribe, J., \& Leatherbee, M. (2018). The effects of business accelerators on venture performance: Evidence from Start-Up Chile. The Review of Financial Studies, 31(4), 1566-1603.

Goswami, K., Mitchell, J.R., \& Bhagavatula, S. (2018). Accelerator expertise: Understanding the intermediary role of accelerators in the development of the Bangalore entrepreneurial ecosystem. Strategic Entrepreneurship Journal, 12(1), 117-150.

Grimaldi, R., \& Grandi, A. (2005). Business incubators and new venture creation: An assessment of incubating models. Technovation, 25(2), 111-121. https://doi. org/10.1016/S0166-4972(03)00076-2.

Hackett, S.M., \& Dilts, D.M. (2004). A systematic review of business incubation research. Journal of Technology Transfer, 29, 55-82.

Hale, T., Petherick, A., Phillips, T., \& Webster, S. (2020). Variation in government responses to COVID-19 (Working Paper, 31). Blavatnik School of Government.

Hallen, B.L., Bingham, C.B., and Cohen, S. (2016). Do accelerators accelerate? The role of indirect learning in new venture development. SSRN 2719810.

Hathaway, I. (2016). What startup accelerators really do. Harvard Business Review. https://hbr.org/2016/03/ what-startup-accelerators-really-do

Hochberg, Y.V. (2016). Accelerating entrepreneurs and ecosystems: The seed accelerator model. Innovation Policy and the Economy, 16(1), 25-51.

Isabelle, D.A. (2013). Key factors affecting a technology entrepreneur's choice of incubator or accelerator. Technology Innovation Management Review, 3(2), 16-22.

Isabelle D.A. (2014). Incubación y aceleración de empresas alrededor del mundo: una revisión de las investigaciones y reflexiones para Colombia. In Edgar Vieira Posada (Ed.), EL TLC Colombia Canadá. Nuevo escenario para el comercio y la inversión (Chap. 5, pp. 155-195). Editorial CESA, Bogotá, D. C.
Isabelle, D.A., Horak, K., McKinnon, S., \& Palumbo, C. (2020). Is Porter's five forces framework still relevant? A study of the capital/labour intensity continuum via mining and IT industries. Technology Innovation Management Review, 10(6), 28-41. http://doi. org/10.22215/timreview/1366

Jackson, P., \& Richter, N. (2017). Situational logic: An analysis of open innovation using corporate accelerators. International Journal of Innovation Management, 21(07), 1750062.

Kanbach, D.K., \& Stubner, S. (2016). Corporate accelerators as recent form of startup engagement: The what, the why, and the how. Journal of Applied Business Research, 32(6), 1761-1776.

Karami, M., Wooliscroft, B., \& McNeill, L. (2019). Effectuation and internationalisation: A review and agenda for future research. Small Business Economics, 1-35.

Kim, J.H., \& Wagman, L. (2014). Portfolio size and information disclosure: An analysis of startup accelerators. Journal of Corporate Finance, 29, 520-534.

Kirby, T. (2020). South America prepares for the impact of COVID-19. The Lancet Respiratory Medicine.

Kohtamäki, M., Parida, V., Patel, P.C., \& Gebauer, H. (2020). The relationship between digitalization and servitization: The role of servitization in capturing the financial potential of digitalization. Technological Forecasting and Social Change, 151, 119804.

Kuckertz, A., Brändle, L., Gaudig, A., Hinderer, S., Reyes, C.A.M., ... \& Berger, E.S. (2020). Startups in times of crisis - A rapid response to the COVID-19 pandemic. Journal of Business Venturing Insights, e00169.

Leatherbee, M., \& Gonzalez-Uribe, J. (2017). The effects of business accelerators on venture performance: Evidence from Start-Up Chile. In Academy of Management Proceedings, 2017(1), Briarcliff Manor, NY.

Lee, S. M., \& Peterson, S. J. (2000). Culture, entrepreneurial orientation, and global competitiveness. Journal of World Business, 35(4), 401-416.

Lumpkin, G.T., \& Dess, G.G. (1996). Clarifying the entrepreneurial orientation construct and linking it to performance. Academy of Management Review, 21(1), 135-172.

Machado, A., da Silva, A., Borba, M., \& Catapan, A. (2015). Innovation habitat: Sustainable possibilities for the society. International Journal of Innovation, $3(2), 67-75$.

Mian, S., Lamine, W., \& Fayolle, A. (2016). Technology business incubation: An overview of the state of knowledge. Technovation, 50, 1-12.

Mintzberg, H. (1978). Patterns in strategy formation. Management Science, 24, 934-948. 
Mthanti, T.S., \& Urban, B. (2014). Effectuation and entrepreneurial orientation in high-technology firms. Technology Analysis \& Strategic Management, 26(2), 121-133.

Nseobot, I.R., Simeon, I.I., Effiong, A.I., Frank, E.I., Ukpong, E.S., \& Essien, M.O. (2020). COVID-19: The aftermath for businesses in developing countries. International Journal of Business Education and Management Studies.

OECD. (2020). A systemic resilience approach to dealing with Covid-19 and future shocks. http://www.oecd. org/coronavirus/policy-responses/a-systemic-resilience-approach-to-dealing-with-covid-19-and-futureshocks-36a5bdfb/

Osterwalder, A., \& Pigneur, Y. (2010). Business model generation: A handbook for visionaries, game changers, and challengers. John Wiley \& Sons.

Osterwalder, A., Pigneur, Y., Bernarda, G., \& Smith, A. (2014). Value proposition design: How to create products and services customers want. John Wiley \& Sons.

Ozili, P.K., \& Arun, T. (2020). Spillover of COVID-19: Impact on the Global Economy. SSRN 3562570.

Pauwels, C., Clarysse, B., Wright, M., \& Van Hove, J. (2016). Understanding a new generation incubation model: The accelerator. Technovation, 50, 13-24.

Radojevich-Kelley, N., \& Hoffman, D.L. (2012). Analysis of accelerator companies: An exploratory case study of their programs, processes, and early results. Small Business Institute Journal, 8(2), 54-70.

Richter, N., Jackson, P., \& Schildhauer, T. (2018). Outsourcing creativity: An abductive study of open innovation using corporate accelerators. Creativity and Innovation Management, 27(1), 69-78.

Sarasvathy, S.D. (2001). Causation and effectuation: Toward a theoretical shift from economic inevitability to entrepreneurial contingency. Academy of management Review, 26(2), 243-263.

Smith, S.W., \& Hannigan, T.J. (2015). Swinging for the fences: How do top accelerators impact the trajectories of new ventures. DRUID15. Rome.

Start-Up Chile. (2020a). https://www.startupchile.org

Start-Up Chile. (2020b). The S Factory. https://www. startupchile.org/programs/the-s-factory/

Stinchcombe, A.L. (1965). Social structure and organizations. Handbook of organizations, 7, 142-193.

Sułkowski, Ł. (2020). Covid-19 pandemic; recession, virtual revolution leading to de-globalization? Journal of Intercultural Management, 12(1), 1-11.

TechCrunch. (2018). Startup accelerators helped spark Latin America's tech boom. https://techcrunch. com/2018/10/04/startup-accelerators-helped-spark-latin-americas-tech-boom/
TechCrunch. (2020). Latin American start-up deals see major drop in COVID-19 era. https://techcrunch. com/2020/04/29/1atin-americas-startup-ecosystem-isnot-immune-to-covid-19/

Teece, D. J. (2012). Dynamic capabilities: Routines versus entrepreneurial action. Journal of Management Studies, 49(8), 1395-1401.

The Engineer. (2020). Covid-19 catalyst for commercial drone deliveries. https://www.theengineer.co.uk/commercial-drone-deliveries-protolabs-report/

TIC Americas. (2020). Umpulsa tu idea de negocio. https://ticamericas.net

UBI Global. (2020). The UBI global world rankings of business incubators and accelerators. https://resources. ubi-global.com/hubfs/Publications/Rankings/UBI\%20 Global\%20-\%20Rankings\%201920\%20v2.pdf

Uhm, C.H., Sung, C.S., \& Park, J.Y. (2018). Understanding the accelerator from resources-based perspective. Asia Pacific Journal of Innovation and Entrepreneurship, 12(3), 258-278.

UN. (2020). Measuring the impact of COVID-19 with a view to reactivation. https://repositorio.cepal.org/bitstream/handle/11362/45477/4/S2000285_en.pdf

Vandeweghe, L., \& Fu, J.Y.T. (2018). Business accelerator governance. In Accelerators. Edward Elgar Publishing.

Wired. (2020). The treat of COVID-19 disrupts the disrupters. https://www.wired.com/story/coronavirus-startup-accelerators-online-y-combinator/

Wise, S., \& Valliere, D. (2014). The impact on management experience on the performance of start-ups within accelerators. The Journal of Private Equity, 18(1), 9-19.

World Bank. (2020). The potential impact of COVID-19 on GDP and Trade. A preliminary assessment. Paper 9211.

WEF (World Economic Forum). (2018). Latin American start-ups are thriving. Let's help them cross borders. https://www.weforum.org/agenda/2018/03/latinamerican-startups-are-thriving-let-s-help-them-crossborders/

WEF (World Economic Forum). (2020). How Latin America can confront COVID-19 tips from former world leaders. https://www.weforum.org/agenda/2020/04/ latin-america-coronavirus-covid19-response-leaders/

Wright, F. (2017). How do entrepreneurs obtain financing? An evaluation of available options and how they fit into the current entrepreneurial ecosystem. Journal of Business \& Finance Librarianship, 22(3-4), 190-200.

Wright, M., Siegel, D.S., \& Mustar, P. (2017). An emerging ecosystem for student start-ups. The Journal of Technology Transfer, 42(4), 909-922.

Yin, B., \& Luo, J. (2018). How do accelerators select startups? Shifting decision criteria across stages. IEEE Transactions on Engineering Management, 65(4), 574-589. 